(3) Shared historical memories

(4) One or more elements of common culture, including "religion, customs, or language"

(5) A link with a homeland

(6) A sense of solidarity "on the part of at least some sections of the ethnie's population." $" 19$

In features (2) and (6), the authors reflect the understanding of Roosens, namely, that ethnicity is a "psychological reality," and even if there is no common ancestry, the individuals can establish themselves with a certain ethnic identity. ${ }^{20}$ By forwarding descriptions and depictions - rather than definitions or essential elements - of ethnicity, anthropologists continue the discourse on ethnic identities with fruitful results; examples of such insights not only stem from the cornucopia of studies on contemporary ethnic groups, but also from the ethnography of historical records like those remaining from Roman Africa. ${ }^{21}$

\title{
5.2 Roman Africa and Ethnic Identity
}

When introducing the compilation he edited, Irad Malkin asks, "Is it legitimate to apply the term 'ethnicity,' invented in the mid-twentieth century, to an ancient phenomenon?"22 Malkin's collaborators, along with what Aaron Johnson calls a "flood of literature" on ethnicity in antiquity, concur with his affirmative answer. $^{23}$ While many historians argue for a primordialist understanding of

19 "Concepts of Ethnicity," 6-7; note Hutchinson and Smith's preference of the French ethnie over the English "ethnicity" or the Russian "ethnos," and that they allow for "ethnic categories" when some of the six features are not prominent.

20 Creating Ethnicity, $15 \mathrm{ff}$.

21 For examples on the use anthropological theories of ethnicity in archaeology, see Philip L. Kohl, "Nationalism and Archaeology: On the Constructions of Nations and the Reconstructions of the Remote Past," ARA 27 (1998): 223-46; and Meskell, "The Intersection of Identity and Politics in Archaeology." On the fact that the "complimentary" processes of ethnicity and globalization have occurred far into the the historical past, see the survey of Gheorghita Geană, "Ethnicity and Globalisation: Outline of a Complementarist Conceptualisation," SA 5 (2 1997): 197-209. For example of anthropologists who compare historical, especially Roman, concepts of ethnicity, see John Armstrong, Nations Before Nationalism, (UNCP, 1982), pages 206-13 reprinted in Ethnicity, ed. Hutchinson and Smith, 120-7; Moses Finley, The Use and Abuse of Ancient History, (London: Hogarth Press, 1986), pages 121-7 and 233-5 are reprinted in Ethnicity, ed. Hutchinson and Smith, 111-6; and William H. McNeill, Polyethnicity and National Unity in World History, (TUP, 1986), pages 14-22 reprinted in Ethnicity, ed. Hutchinson and Smith, 107-11.

22 "Introduction," Ancient Perceptions of Greek Ethnicity, ed. Malkin, (HUP, 2001), 3.

23 Johnson, "Identity, Descent, and Polemic: Ethnic Argumentation in Eusebius' Praeparatio Evangelica," JECS 12 (1 2004), n.21. Also, cf. Stephen Mitchell and Geoffrey Greatrex, "Introduction," Ethnicity and Culture in Late Antiquity, ed. Mitchell and Greatrex, (London: 
ethnicity, as some anthropologists were shown to do in the last chapter, such debates will be tabled in the following section, following the understanding of ethnicity where specific indicators of ethnic identity can be interpreted as a boundary between groups. ${ }^{24}$ Where most historians agree with anthropologists, however, is in the understanding that ethnic identities are constructed in terms of difference.

As seen with other forms of identity, ethnic groups construct their identity by distinguishing themselves from an ethnic "Other." 25 The ethnic "Other," moreover, allowed ancients to construct for themselves multiple ethnic identities. A few examples discussed by historians include (1) Lucian, Syrian and "international"; (2) Cassius Dio, Bithynian, Roman and Greek; (3) Augustine, North African, Christian and Roman; (4) Paul, of Tarsus, Roman and Jewish; and (5) Strabo, from Pontus, "barbarian," Roman and Greek. ${ }^{26}$ Ethnic identities in the ancient world were complex, discursive, manifold and sometimes even contradictory, as seen in the ethnic identities of Roman colonizers, indigenous Africans and new elites. ${ }^{27}$

Roman ethnic identity has proved difficult to define, as shown in the above discussions of Romanization and romanitas. As Roman power expanded, and Romans colonized the provinces, it could be said that "...many Roman writers seem to insist on differences between themselves and others as a way of justifying the conquest of these populations." 28 On the other hand, each source must be interpreted in light of specific contextual items, because, as Michael Dewar argues in his article, "We're All Romans Now (Except for the Foreigners)," Romans could at times portray provincials as the barbarian "Other," and at other times incorporate provincials into their own ethnic identity. ${ }^{29}$ In order to see how

Duckworth, 2000). See Denise McCoskey, "Answering the Multicultural Imperative: A Course on Race and Ethnicity in Antiquity," CW 92 (6 1999), 553-4, on the "divisive" subject in Classics.

24 e.g. Huskinson, "Looking," 11, says, "But 'essentialism' is not just a modern view. There are also some indications of it in the Roman world." Also, Jonathan M. Hall, Ethnic Identity in Greek Antiquity, (CUP, 1997), 17-26, argues for a primordialist understanding. Opposed to such a view is Johnson, "Identity," 29.

25 On Greeks, Hall, Ethnic Identity, 33; on Romans, Huskinson, "Looking," 14; regarding the ancient near east, Mendels, Identity, 19; and in the provinces, Mitchel and Greatrex, "Introduction," xiii

26 On Lucian, John Matthews, "Roman Law and Barbarian Identity in the Late Roman West," in Ethnicity and Culture, ed. Mitchell and Greatrex, 31. On Cassius, Augustine and Paul, Mitchell and Greatrex, "Introduction," xiii. On Strabo, Edward van der Vliet "The Romans and Us: Strabo's Geography and the Construction of Ethnicity," Mnemosyne 56 (3 2003), 269-70.

27 Carla M. Antonaccio, "Ethnicity and Colonization," in Ancient Perceptions, ed. Malkin, 113157.

28 McCoskey, "Answering," 556.

29 "We're All Romans Now (Except for the Foreigners): Multi-Ethnic Armies and the Ideology of Romanitas in the Poetry of Claudian," SCl 14 (2003): 143-159. van der Vliet, "The Romans and Us," 270 , describes the phenomenon in terms of "narrowing, concentric circles." 
Romans constructed their own ethnic identity, one can turn to the boundary markers employed by Romans in describing the ethnic "Other."

Romans could incorporate and/or exclude other collectivities in their ethnic identity by establishing various boundary markers. When factors such as language, customs or even appearance are correlated by Romans to a particular group of people, they are here understood to be boundary markers of ethnicity. ${ }^{30}$ At times, Romans could invoke their Trojan ancestry as an ethnic boundary while other times accepting the notion of common descent with provincials. ${ }^{31}$ Another example is the Roman toga, which became "loaded with moral significance" to those colonizing the provinces, especially in contrast to the pallium, a garment "unsuitable to be worn by Romans." 32 Another element that influenced Roman's construction of ethnic identity, although not a precise boundary marker, was the way in which Romans, especially well-educated Romans, divided the world into three regions: (1) the northern, cold climate inhabited by the Scythians who were light skinned and light haired; (2) the southern, hot climate inhabited by the Ethiopians with dark skin; and (3) the middle, temperate zone, with Greece and Italy in the center. ${ }^{33}$ The spectrum flowed north to south, white to black establishing Romans as the perfect balance. Thompson argues that this view never led to racism as it would be academically defined today but rather to ethnocentrism. ${ }^{34}$ The ethnocentric tendency inherent in the Roman colonizers helps elucidate how they identified themselves and others: the more Roman, the more civilized.

To the Romans and the Roman colonizers, the indigenous Africans bore certain traits that served as ethnic boundaries. One of the minor poems of (Ps.)Virgil states, "She was his only help, African by race, her whole appearance proclaiming her native land." ${ }^{35}$ The fact that an outsider could look at a woman and know by her figura that she was an Afra suggests that there were physical signifiers by which North Africans were recognized. Snowden, who seeks to

30 e.g. Tacitus, Germania 4, "habitus corporum" ('physique'); 28, "institutus moribus" ("habits,' and 'type of character'); 45 "ritus habitusque" ("customs and dress"); and 'lingua' ('language'); for a discussion of Tacitus' usage, see Walter Pohl, "Telling the Difference: Signs of Ethnic Identity," in Strategies of Distinction: The Construction of Ethnic Communities, 300800, ed. Pohl and Helmut Reimitz, (Leiden: Brill, 1998), 17-70. See Hall, Ethnic Identity, 17781 , for the importance of language in ethnic identities.

31 Sue Elwyn, "Interstate Kinship and Roman Foreign Policy," TAPA 123 (1993): 261-288.

32 "...loaded...," in Woolf, "Becoming Roman," 130. "...unsuitable...," in Huskinson, "Looking," 9. Also, see Strabo's understanding of dress in van der Vliet, "The Romans and Us," 264.

33 Frank M. Snowden, Jr., Blacks in Antiquity: Ethiopians in the Greco-Roman Experience, (Cambridge, Mass.: The Belknap Press of Harvard University Press, 1970), 171ff; cf. Thompson, Romans and Blacks, 100ff. While these authors primarily concern themselves with Ethiopians, they serve to further the understanding of ethnic identity in Roman North Africa by interpreting ethnicity from the perspective of non-Romans.

34 Romans, 112-120; Mitchell and Greatrex, "Introduction," xii.

35 Moretum 31-2: erat unica custos, Afra genus, tota patriam testante figura. 
reconstruct the actual somatic type of North Africans, explains, "The child of a white mother and an Ethiopian father was decolor (discolor). These two words were often used to describe the skin color of the peoples of India and Mauretania. Hence, the Roman usage of these words to describe children born of Ethiopian and white parents suggests that the children of such unions resembled in color the lighter Indians and Mauretanians." the skin color of North Africans compared with Ethiopians and Romans, when he states, "The very darkskinned Berber group known as the Aphodelodes is likewise described as resembling Aethiopes only in colour but not in morphology. The ethnic label Melanogaetuli (black Gaetulians) is similarly a coinage reflecting the fact that this southern Berber people combined normal Mediterranean morphology with a very dark complexion." ${ }^{37}$ Sometimes Afer (African) was even used by Romans as the equivalent of Aethiops (i.e. blackskinned). ${ }^{38}$ This, however, was usually due to a lack of familiarity with darker skinned people. ${ }^{39}$ Fearing racializing tendencies, scholars like Gruen have questioned the use of "appearance" or skin-color in ethnic studies. ${ }^{40}$ What should the scholar do, however, when Roman sources use appearance as an ethnic boundary? Art historians, for example, have commented on the way in which Africans were portrayed differently from Romans. ${ }^{41}$ It seems that to the Roman colonizers, the Africans were darker than themselves, yet not as dark as the Ethiopians further south. Other ethnic boundaries were also formed between the Romans and the Africans by dress: Roman and Greek sources often portray Africans as nomadic barbarians wearing the "mantle" or the pallium instead of

\section{Blacks, 4.}

37 Romans, 61.

38 See Snowden, Blacks, 11, for examples.

39 Ibid.

40 "Cultural Fictions," 3.

41 For depictions in art, see Michèle Blanchard-Lemée, Mongi Ennaïfer, Hédi Slim and Latifa Slim, Mosaics of Roman Africa: Floor Mosaics from Tunisia [Sols de l'Afrique Romaine], trans. Kenneth D. Whitehead, (London: British Museum Press, [1995]1996), 19-22, who examines representations of the goddess Africa depicted with dread locks, "brunettecomplexioned," "notably darker" and having "Negroid traits of the whole face." Huskinson, "Looking," 14, comments, "This is particularly interesting to note in the case of Africa, since the other mosaic image of her found in the house emphasizes more 'ethnic' features by giving her corkscrew curls, large eyes, and darker skin." Also, Marshall, "The Self," 49-63, lists examples of artistic depictions of Cyrenaeans depicting themselves and Romans with "Libyan features." Similarly, see Gilbert Charles-Picard and Colette Charles-Picard, Daily Life in Carthage at the Time of Hannibal, trans. A.E. Foster, (London: Ruskin House, 1961), 129, for the archeological examinations of skeletons found at the site of the ancient city of Carthage and the discussion of a variety of somatic types with a majority of "African" or "Negro" types. 
togas. $^{42}$ Similarly, African dialects and Punic remained in wide usage at least until the end of the second century. ${ }^{43}$

The encounter between the Romans and the other ethnic groups in the provinces resulted in a pressure on new elites to "become ... Roman by adopting the Roman way of life, by speaking their language, by adopting their politeia." Because of the "ethnocentricity" of the Roman colonizers in viewing the indigenous Africans, the self-identity of new elites included an awareness of their own African ethnic identity. ${ }^{45}$ Several examples in the sources indicate that Africans perceived certain of their characteristics and customs to have been defined by Roman colonizers as ethnic boundary markers.

Terentius Afer is an early example of this self-awareness, with Afer ("the African") placed in his Roman name by his owner. ${ }^{46}$ Similarly, Fronto once had to excuse his accent by comparing himself to the "barbarian" Anacharsis who was known for his wisdom: "for he was a Scythian of the nomad Schythians, while I am a Libyan of the nomad Libyans." ${ }^{47}$ Champlin, recognizing this self-awareness of ethnicity in Fronto, states,

This contrast [between Fronto and the Graeco-Romans] suggests the key to what was truly "African" in the orator. Above all, Fronto was the learned man of his age, thoroughly familiar with both Greek and Latin culture and the standard-bearer of Latin letters. His only misfortune was that he was born neither Greek nor Roman, but African. ...Considerable evidence suggests in the educated elite of Roman Africa a conscious suppression of the non-Latin heritage, a practice in marked contrast with that of the Hellenized East. The lingua punica was not a source of pride, most particularly in the late first and early second centuries, just when Africans were first beginning to penetrate the courts, the salons, and the senate of Rome. ${ }^{48}$

42 Huskinson, "Looking," 8; and Marshall, "The Self and the Other in Cyenaica," 57, who cites examples.

43 Cherry, "Marriage," 71; Miles, "Communicating Culture," 58; and Miller, "Local Cultures," 130-3; for sources and discussion. Also, Hall, Ethnic Identity, 177-81, for the importance of language in ethnic identities.

44 van der Vliet, "The Romans and Us," 269; cf. Hutchinson and Smith, "Concepts of Ethnicity," in Ethnicity, ed. Hutchinson and Smith, 10-11.

45 Richard Alston, "Philo's In Flaccum: Ethnicity and Social Space in Roman Alexandria," G\&R 2nd ser. 44 (2 1997): 165-175, for the case of Egypt, where the Romans elevated the status of Hellenized, urban elites over rural Egyptians as a means of stratifying and controlling Alexandrian society.

46 Snowden, Blacks, 188.

47 See above. Miller, "Local Cultures," 126-134, discusses "native" languages of Africa (Punic and Lybian) remaining throughout the Roman period. cf. Augustine, De ciuitate Dei, 16.6, "For even in Africa we know several barbarous nations which have but one language" [Nam et in Africa barbaras gentes in una lingua plurimas nouimus.]

48 Fronto, 16 
Fronto represents just one of many new elites of North Africa with a selfawareness of their ethnic identity. ${ }^{4}$

Other sources also imply that new elites from North Africa struggled with a stigmatized ethnic identity. John Hilton recognizes the same phenomenon in Apuleius:

Since his place of birth was Madauros in Africa Proconsularis, his native language (sermo patrius) was probably Punic. ...His linguistic background is therefore complex and this was no doubt the reason why he had to watch his words carefully. He would otherwise no doubt have been disparaged by his rivals, as was the emperor Septimius Severus who "had a melodious voice but sounded like an African somehow right up to his old age." An emperor could afford not to be too concerned on this account, but a sophist would need to be more watchful." 50

Raven adds to this point of the self-awareness of Septimius Severus, "An African from Leptis Magna, named Septimius Severus, was once congratulated by the poet Martial 'that nothing in his looks or speech betrayed his Punic origin.' His relative of the same name who became the first African emperor 'never lost his African accent, and his Punic-speaking sister, on a visit, is said to have shamed him with her broken Latin." 51 More generally on new elite usage of language, Richard Miles explains, "In north Africa, with the emergence of a RomanoAfrican elite in the first century AD, bilingual inscriptions in both Latin and Punic reflect this elite's need to not only maintain its local power base with a selfconsciously constructed 'African' cultural identity, but also to articulate its position as an important group of people within the framework of the Roman

49 See Koen Goudriaan, Ethnicity in Ptolemaic Egypt, (Amsterdam: J.C. Gieben, 1988), for the example of Hellenistic Egypt where the tensions between the colonizer and the colonized created an ethnic awareness among the new Greek-speaking elites of Egypt.

50 "Introduction," 126; ref. to Flor. 9.6-7, "This is especially true for me, since the reputation that I have already won and your kind confidence in me does not allow me to mouth anything I like off the top of my head. For who among you would forgive me for a single solecism? Who would allow me one ignorantly pronounced syllable? Who would permit me to jabber any wild and uncouth words like those that well up in the mouth of the insane? Yet you easily forgive others for these same faults and quite justly so" [praesertim mihi, cui et ante parta existimatio et uestra de me benigna praesumptio nihil non quicquam sinit neglegenter ac de summo pectore hiscere. Quis enim uestrum mihi unum soloecismum ignouerit? Quis uel unam syllabam barbare pronuntiatam donauerit? Quis incondita et uitiosa uerba temere quasi delirantibus oborientia permiserit blaterare? Que tamen aliis facile et same meritissimo ignoscitis]; and ref. to Scriptores historiae augustae, Seuerus, 19.9: canorus uoce, sed Afrum quiddam usque ad senectutem sonans.

51 Rome, 132; ref. Scriptores historiae augustae, Seuerus, 15.7: cum sua Leptitana ad eum uenisset uix Latine loquens, ac de illa multum imperator erubesceret. Also, see Birley, The African Emperor, 36, "The muddled Antiochene chronicler John Malalas, four centuries later, says that Septimius was dark-skinned. There is not much chance of verifying this statement now (although one colour portrait has survived)." A gray-scaled version is in Birley's plate 16. 
empire." 52 Apuleius, Septimius Severus and other examples illustrate how new elites, conscious of language as an ethnic boundary markers established by the Roman "Other," attempted to transcend their own African ethnic identity.

Recognizing patria, or homeland, as a constructed ethnic boundary by some, Apuleius protested,

I proclaimed myself to be "half Numidian" and "half Gaetulian." Now I cannot see what I should be ashamed of, any more than Cyrus the Great because he was of mixed birth, being half Mede and half Persian. You must not judge a man's district of origin but his disposition, not where but how he has commenced to live. ...To be sure, some nations seem remarkable for their stupidity or smartness, but the wise Anacharsis was born among the inert Scythians and the foolish Meletides among the clever Athenians. $^{53}$

All of these examples suffice to show that the new elites of Africa understood their ethnic identity as a hindrance.

The varying responses to Roman colonizers who often established ethnic boundaries highlight the complexities of identity in the postcolonial context, a point noted by van der Vliet in his discussion of a "definition of ethnicity":

But in the meantime we crossed another kind of boundary, because the distinction between Romans and non-Romans has a wider range than inside the citizenries of individual cities. It is independent of these, and stands besides them. Among "Romans" circles of identity should be drawn in respect of their distance from the centre of power: the emperor and his family, the higher administrators and commanders, and next those who support them in the exercise of their tasks - and here Strabo places himself - , and, finally, the subject population. ... The well known principle, that who you are depends on context, applies also here. ${ }^{54}$

The question of "power" and loyalty to the emperor will reemerge below in regard to the new elites; for the present purposes, van der Vliet's statement helps explain the ethnic identities of new elites. Walter Pohl also clarifies this point by stating, "Romanness, even for those who reached this goal, did not cancel regional and ethnic identities." and even Septimius Severus oscillated between the ethnic identities available to them, including Roman and African.

52 “Communicating Culture," 58-9.

53 Apologia 24: professus sum... Seminumidam et Semigaetulum, non video quid mihi sit in ea re pudendum, haud minus quam Cyro maiori, quod genere mixto fuit Semimedus ac Semipersa. Non enim ubi prognatus, sed ut moratus quisque sit spectandum, nec qua regione, sed qua ratione uitam uiuere inierit, consideratum est. ...quamquam uideantur quaedam stultitia uel sollertia insigniores? Apud socordissimos Scythas Anacharsis sapiens natus est, apud Athenienses catos Meletides fatuus.

54 "The Romans and Us," 271.

55 "Introduction: Strategies of Distinction," in Strategies of Distinction, ed. Pohl and Reimitz, 1. 